\title{
PENGELOLAAN LAHAN BANTARAN SUNGAI BEDOG BERBASIS KOMUNITAS KARANG TARUNA GUNA MENDUKUNG PEMBANGUNAN BERKELANJUTAN
}

\author{
Alfin Julianto $^{1 *}$, Iis Prasetyo ${ }^{2)}$ \\ ${ }^{1)}$ Program Magister Pendidikan Nonformal, Universitas Negeri Yogyakarta \\ ${ }^{2}$ Program Magister Pendidikan Nonformal, Universitas Negeri Yogyakarta \\ *Email: alfinjulianto.2017@ student.uny.ac.id
}

\section{ABSTRACT \\ BEDOG RIVER MANAGEMENT BASED ON KARANG TARUNA COMMUNITIES TO SUPPORT SUSTAINABLE DEVELOPMENT}

This article is intended to discuss the process of community empowerment through the management of the Bedog River bank to support the pillars of sustainable development and great support from the management of the Bedog River in Munengan Hamlet, Sidoluhur Village, Godean District, Sleman Regency, Yogyakarta.This research is a descriptive qualitative research type. The subjects of this study were managers of fish ponds, youths of youth in Munengan Hamlet, Sidoluhur Village, and community of Munengan Hamlet, Sidoluhur Village.Data collection is done by using observation, interview, and documentation techniques.Data analysis techniques are data collection, data reduction, data presentation, and conclusion. The validity of research data using source triangulation and methods. The results of this study are: First, community empowerment through the Karang Taruna Bakti Community as an effort to manage the Bedog River bank starts from the process of awareness, reflection, and action on the management of river banks by planting water guava and passion fruit plants.Second, efforts to utilize riverbanks are beneficial for the riverbank environment and the community of Munengan Hamlet, Sidoluhur Village. The guava and passion fruit plants will produce fruit and the trees can preserve the ecology of the Bedog River banks from abrasion and support the pillars of sustainable development.

Keywords: Management, Riverbanks, Sustainable Development, Karang Taruna Community

\section{PENDAHULUAN}

Dewasa ini, problematika terkait dengan bantaran sungai menjadi isu yang sensitif dalam fenomena sosial. Hal tersebut terbukti dengan banyaknya kawasan bantaran sungai yang tercemar oleh limbah rumah tangga maupun limbah pabrik. Akibatnya, terjadi kerusakan pada ekosistem di sekitar sungai. Berdasarkan hal tersebut, fenomona bantaran sungai menjadi hal yang krusial untuk itu perlu adanya gerakan perubahan sosial yang dilakukan secara masif oleh berbagai pihak untuk mendukung ekosistem sungai yang berkelanjutan.

Merujuk pada istilah bantaran sungai berdasarkan Peraturan Pemerintah RI No. 38 Tahun 2011 tentang sungai merupakan ruang antara tepi palung sungai dan kaki tanggul sebelah dalam yang terletak dikiri dan/atau kanan palung sungai. Bantaran sungai kerap kali dijadikan objek vital oleh masyarakat menengah ke bawah untuk menunjang aktivitas sehari-hari. Namun, kebiasaan tersebut menimbulkan kerusakan yang berarti di daerah bantaran sungai yang berakibat pada ekosistem sungai. Realitas seperti itu, kerap ditemukan di kota-kota besar salah satunya adalah Yogyakarta. Hasil penelitian menunjukan bahwa kerusakan ekosistem aliran sungai mempengaruhi daya dukung sumberdaya air di Pulau Jawa dan meningkatkan frekuensi terjadinya banjir dan longsor serta mudahnya terjadi kekeringan yang diakibatkan oleh kerusakan struktur di dalam tanah (Mawardi, 2010).

Kerusakan yang terjadi di bantaran sungai hingga saat ini seolah belum ada titik 
temu sebagai upaya untuk memperbaikinya. Hal tersebut terjadi karena belum adanya contoh konkret yang bergerak untuk mengatasi permasalahan sosial tersebut. Untuk itu, perlunya penyadaran kepada masyarakat akan pentingnya menjaga dan melestarikan ekosistem lingkungan bantaran sungai.

Fenomena sosial itu ditemukan di Dusun Munengan Desa Sidoluhur, Kecamatan Godean, Sleman, Yogyakarta. Di daerah ini terdapat aliran sungai yang berada tepat di sekitaran pemukiman masyarakat yaitu aliran Sungai Kontheng dan Sungai Bedog. Sungai ini mengalami permasalahan karena ditemukannya sampah-sampah hasil rumah tangga yang mencemari air sungai. Selain itu, belum adanya penataan tanaman-tanaman di sekitar bantaran sungai menjadi polemik yang fundamental. Hal tersebut akan berakibat fatal pada saat terjadinya hujan dengan intensitas yang tinggi. Sujarto (1993) menyatakan bahwa permasalahan sampah pada daerah bantaran sungai disebabkan karena adanya peningkatan jumlah penduduk, pertumbuhan industri, pembangunan dan perkembangan kota, kepadatan lalu lintas, deforestasi, dan sebagainya. Sedangkan untuk melakukan penanganan masalah-masalah seputar penataan bantaran sungai hal tersebut perlu dukungan yang luar biasa baik dari segi waktu, tenaga, biaya, dan kesadaran dari masyarakat itu sendiri untuk memperbaiki permasalahan tersebut.

Di sisi lain aliran sungai ini belum dimanfaatkan oleh mayarakat sebagai lahan bantaran sungai yang bisa bermanfaat bagi lingkungan dan masyarakat. Padahal esensinya, memanfaatkan bantaran sungai menjadi lahan yang produktif akan berdampak pada kesejahteraan lingkungan dan masyarakat. Apabila hal tersebut telah terwujud makakeuntungan yang diperoleh dari pengelolaan bantaran sungai yang baik adalah terciptanya perbaikan ekologi demi terciptanya pembangunan berkelanjutan. Selain itu, dilihat dari sisi ekologi tata kelola bantaran sungai juga memiliki keuntungan lain, yakni terpeliharanya keragaman hayati dan kebersihan bantaran sungai. Sehingga dengan penataan bantaran sungai yang baik akan berdampak baik pula kelestarian lingkungan yang berkelanjutan. Manfaat lain dari pengelolaan bantaran sungai yang tidak dapat diabaikaan adalah fungsi penghasil jasa yang tidak tampak nyata (intangible) terutama dalam hal stabilisasi kualitas lingkungan, seperti: memitigasi banjir, pengendali erosi tanah, pemelihara pasokan air tanah, penyejuk dan penyegar udara, dan pemelihara keanekaragaman hayati.

Pemanfaatan lahan bantaran sungai untuk pemeliharaan berbagai komoditi secara bersama-sama (kombinasi) atau berurutan antara tanaman pohon (hutan) dengan komoditi pertanian (tanaman, ternak, dan atau ikan/kolam) secara optimal merupakan sebuah sistem pertanian terpadu yang tidak hanya memberikan hasil nyata (tangible) produk pertanian dan kehutanan, namun sekaligus berperan dalam pelestarian lingkungan berupa kesejukan, kesegaran, keindahan, biodiversitas, dan bahkan membantu memitigasi gas rumah kaca (produk intangible) di kawasan pemukiman secara berkelanjutan.

Manfaat sungai antara lain adalah sebagai tempat budidaya ikan, tempat rekreasi, pengairan, sumber air baku bagi untuk menciptakan microhidro, dan lain-lain. Akan tetapi keberadaan sungai tersebut akan sangat berbahaya jika tidak dilakukan pengendalian serta pengawasan pembangunan pada sempadan sungai dan badan sungai karena dapat menyebabkan terjadinya penyempitan badan sungai, bahkan dapat menimbulkan bahaya-bahaya lain bagi lingkungan di masyarakat. Salah satunya ialah banjir, erosi, dan tanah longsor yang kerap menyebabkan bencana akibat dari aliran sungai yang kondisinya buruk dan tidak terjaga di beberapa kota besar di Indonesia termasuk di Kota Yogyakarta.

Follet (1997) mendefinisikan pengelolaan ialah seni atau proses dalam menyelesaikan sesuatu yang terkait dengan pecapaian tujuan. Dalam penyelesaian akan sesuatu tersebut, terdapat tiga faktor yang terlibat yiatu: (1) adanya penggunaan sumber daya organisasi, baik sumber daya manusia maupun faktor-faktor produksi lainya, (2) proses yang bertahap mulai dari perencanaan, pengorganisasian, pengarahan, dan pengimplementasian, hingga pengendalian 
dan pengawasan, dan (3) adanya seni dalam penyelesaian pekerjaan. Pengelolaan adalah suatu cara atau proses yang dimulai dari perencanaan, pengorganisasian, pengawasan, dan evaluasi untuk mencapai suatu tujuan yang telah ditentukan agar berjalan efektif dan efisien.

Pengelolaan bantaran sungai menjadi lingkungan ekologi yang tertata dengan baik akan mendukung pilar gerakan pembangunan berkelanjutan (sustainable development goals) yaitu penataan lingkungan yang bersih, ekosistem yang terjaga, kualitas udara dan air yang bersih. Berdasarkan, United States Environmental Protection Agency (USEPA) memiliki wawasan untuk mewujudkan pembangunan yang berkelanjutan melalui tiga pilar pendekatan pembangunan berkelanjutan, yaitu: pilar lingkungan, pilar ekonomi, dan pilar sosial (USEPA, 2013 dalam Abdoellah, 2016). Gerakan ini hendaknya didukung oleh berbagai kalangan baik dari kalangan pemerintah, kalangan akademisi, praktisi di masyarakat dan masyarakat itu sendiri. Gerakan bersama menciptakan lingkungan bantaran sungai yang bersih dan tertata dengan baik. Untuk mewujudkan kondisi yang diinginkan itu tentulah butuh proses tidak bisa dicapai dengan instan.

Salah satu langkah yang bisa dilakukan adalah melalui komunitas pemuda desa atau karang taruna setempat sebagai generasi yang diharapkan akan memberi perubahan di desa tempat tinggalnya. Komunitas karang taruna adalah wadah pengembangan generasi milenial dan putusan yang tumbuh atas dasar kesadaran dan rasa tanggung jawab sosial dari masyarakat, oleh masyarakat, dan untuk masyarakat, khususnya generasi milenial di wilayah desa/kelurahan atau komunitas sosial sederajat sampai tingkat nasional, bergerak terutama di bidang kesejahteraan sosial (AD KTI, pasal 4). Komunitas karang taruna ini dimaksudkan untuk menumbuhkan kesadaran pemuda (generasi milenial) agar memiliki kepedulian terhadap pemeliharaan dan perbaikan lingkungan. Salah satunya ialah Komunitas Karang Taruna Bakti Dusun Munengan Desa Sidoluhur yang dibentuk dan beranggotakan pemuda setempat sebagai wadah pengembangan diri pemuda, memelihara dan memperbaiki lingkungan di tempat mereka berdomisili sehingga terwujudnya pemuda yang peduli lingkungan dan menjadi penggerak pengembangan desa yang mengarah pada pembangunan berkelanjutan.

Program kerja Komunitas Karang Taruna Bakti Dusun Munengan Desa Sidoluhur salah satunya adalah pemanfaatan lahan bantaran Sungai Bedog untuk meningkatkan perekonomian dan memelihara kelestarian lingkungan bantaran sungai melalui tata kelola bantaran Sungai Bedog di Dusun Munengan Desa Sidoluhur. Sehingga dengan adanya tata kelola lingkungan bantaran Sungai Bedog diharapkan akan memberikan dampak positif terhadap lingkungan bantaran sungai yang terpelihara kelestariannya. Oleh karena itu, dalam artikel ini menyajikan proses pemberdayaan masyarakat melalui pengelolaan bantaran Sungai Bedog berbasis komunitas karang taruna guna mendukung pilar pembangunan berkelanjutan.

\section{METODOLOGI}

Penelitian ini menggunakan metode penelitian kualitatif deskriptif. Penelitian kualitatif merupakan jenis penelitian yang digunakan untuk melihat proses pemberdayaan masyarakat melalui pengelolaan bantaran sungai guna mendukung pembangunan berkelanjutan dan seberapa besar manfaat dari pengelolaan bantaran Sungai Bedog di Dusun Munengan Desa Sidoluhur. Adapun teknik pengumpulan data melalui observasi, wawancara, dan dokumentasi. Teknik analisis data dengan cara pengumpulan data, reduksi data, penyajian data, penarikan kesimpulan. Keabsahan data penelitian dengan menggunakan trianggulasi sumber dan metode. Sumber data atau informan dalam penelitian ini yaitu, Tokoh masyarakat, Ketua Karang Taruna Bakti, Anggota Karang taruna Bakti di Dusun Munengan Desa Sidoluhur, dan masyarakat Dusun Munengan Desa Sidoluhur. 


\section{HASIL DAN PEMBAHASAN}

\subsection{Gambaran Umum}

\subsubsection{Deskripsi Lokasi}

Dusun Munengan Desa Sidoluhur termasuk dalam wilayah Kecamatan Godean, Kabupaten Sleman, Daerah Istimewa Yogyakarta. Dilihat dari letak astronomis, Desa Sidoluhur terletak pada $110^{\circ} 16^{\prime} 45^{\prime \prime}$ BT$110^{\circ} 20^{\prime} 01^{\prime \prime} \mathrm{BT}$ dan $7^{\circ} 44^{\prime} 11^{\prime \prime} \mathrm{LS}-7^{\circ} 47^{\prime} 16^{\prime \prime} \mathrm{LS}$. Dusun Munengan memiliki luas wilayah \pm 24 ha, sedangkan Desa Sidoluhur sendiri memiliki luas wilayah 489,340 Ha dengan ketinggian tempat 113 Mdpl. Jarak Desa Sidoluhur dari pusat pemerintahan kecamatan adalah $2 \mathrm{~km}$, jarak dari pusat pemerintahan kabupaten $10 \mathrm{~km}$, jarak dari pusat pemerintahan propinsi $12 \mathrm{~km}$.

Secara administratif, batas wilayah Desa Sidoluhur adalah sebagai berikut:

Sebelah Utara : Desa Margoluwih,

Kecamatan Seyegan

Sebelah Barat : Desa Sidorejo,

Kecamatan Godean.

Sebelah Selatan : Desa Sumbersari,

Kecamatan Moyudan.

Sebelah Timur : Desa Sidoagung, Kecamatan Godean.

Di Dusun Munengan Desa Sidoluhur memiliki aliran sungai yaitu aliran sungai Bedog yang berada di sekitar perumahan warga. Sungai ini kemudian memiliki bantaran yang di beberapa lokasi masih belum di manfaatkan. Luas bantaran Sungai Bedog ini sekitar $\pm 10-15 \mathrm{M}$ di sebelah kiri dan kanan sungai.

\subsubsection{Komunitas Karang Taruna Bakti}

Karang Taruna Bakni bergerak di bidang pendidikan, pelatihan dan penyuluhan, usaha kesejahteraan sosial, pengabdian masyarakat, keuangan dan kewirausahaan, kerohanian dan pembinaan mental, olahraga dan seni budaya, hubungan masyarakat dan lingkungan hidup. Salah satu program yang dituangkan dalam artikel ini yaitu di bidang hubungan masyarakat dan lingkungan hidup. Lingkungan hidup terkait dengan pengelolaan bantaran Sungai Bedog yang terdapat di tempat tinggal pemuda karang taruna di Dusun Munengan Desa Sidoluhur.
Setiap bulan anggota karang taruna mengadakan pertemuan rutin membahas mengenai program-program kerja yang akan dilaksanakan. Selain itu ada juga kegiatan setiap satu bulan sekali mengadakan kerja bakti yaitu membersihkan lingkungan sekitar dan bantaran sungai di Dusun Munengan. Hal ini bertujuan supaya menanamkan kepada para pemuda di Dusun Munengan supaya sadar akan pentingnya menjaga lingkungan sekitar agarnlingkungan bersih dan masyarakat sehat.

Komunitas Karang Taruna Bakti adalah Karang Taruna Dusun Munengan yang beranggotakan pemuda-pemudi Dusun Munengan Desa Sidoluhur. Karang Taruna Bakti ini pada tahun 2018-2020 di ketuai oleh Fajar Sulistio. Setiap 3 (tiga) tahun Komunitas Karang Taruna Bakti berganti kepengurusan.

Adapun Struktur Organisasi Karang Taruna Bakti di Dusun Munengan Desa Sidoluhur, yaitu sebagai berikut:

Tabel 1. Srtuktur Organisasi Karang Taruna Bakti Dusun Munengan Desa Sidoluhur

\begin{tabular}{|l|l|l|}
\hline \multicolumn{1}{l}{ Jo } & \multicolumn{1}{l}{ Nama } \\
\hline 1. & Ketua & Fajar Sulistyo \\
\hline 2. & Wakil ketua & Deki Mustofa \\
\hline 3. & Sekretaris & Arta \\
\hline 4. & Bendahara & Suci Lakmana \\
\hline 5. & $\begin{array}{l}\text { Bidang } \\
\text { Kesekretariatan }\end{array}$ & Meri Latifa Putri \\
\hline 6. & $\begin{array}{l}\text { Bidang Usaha } \\
\text { Kesejahteraan Sosial }\end{array}$ & Dani Putra \\
\hline 7. & $\begin{array}{l}\text { Bidang Usaha } \\
\text { Ekonomi Produktif }\end{array}$ & Rio Nugroho \\
\hline 8. & $\begin{array}{l}\text { Bidang Pendidikan } \\
\text { dan Latihan }\end{array}$ & Rendi Jayadi \\
\hline 9. & Bidang Keagamaan & Rahmat Hamdi \\
\hline 10. & $\begin{array}{l}\text { Bidang Pengabdian } \\
\text { Masyarakat }\end{array}$ & Suryaman \\
\hline 11. & $\begin{array}{l}\text { Bidang Olahraga dan } \\
\text { Seni }\end{array}$ & Govin Meriansyah \\
\hline
\end{tabular}

Karang Taruna Bakti Dusun Munengan Desa Sidoluhur memiliki tujuan, tugas, fungsi dan program-program yang mengacu pada Permensos 83/HUK/2005 tentang Pedoman Dasar Karang Taruna. 


\section{a) Tujuan Karang Taruna Bakti}

Tujuan Karang Taruna Bakti ini mengacu pada Permensos 83/HUK/2005 tentang Pedoman Dasar Karang Taruna, yaitu:

1. Terwujudnya pertumbuhan, perkembangan, kesadaran, dan tanggung jawab sosial setiap generasi milenial warga karang taruna dalam mencegah, menangkal, menanggulani, dan mengantisipasi berbagai masalah sosial.

2. Terbentuknya jiwa dan semnagat juang generasi milenial warga karang taruna yang terampil dan berkepribadian serta berpengetahuan.

3. Tumbuhnya potensi dan kemampuan generasi milenial dalam rangka mengembangkan keberdayaan warga karang taruna.

4. Termotivasinya setiap generasi milenial warga karang taruna untuk mampu menjalin toleransi dan menjadi perekat persatuan dalam keberagaman kehidupan bermasyarakat, berbangsa, dan bernegara.

5. Terjalinnya kerjasama antar generasi milenial warga karang taruna dalam rangka mewujudkan taraf kesejahteraan sosial bagi masyarakat.

6. Terwujudnya kesejahteraan sosial yang semakin meningkat bagi generasi milenial di desa/kelurahan atau komunitas yang memungkinkan pelaksanaan fungsi sosialnya sebagai manusia pembangunan yang mampu mengatasi masalah kesejahteraan sosial di lingkugannya.

7. Terwujudnya pembangunan kesejahteraan sosial generasi milenial di desa/kelurahan atau komunitas yang dilaksanakan secara komprehensif, terpadu, dan terarah serta berkesinambungan oleh karang taruna bersama pemerintah dan komponen masyarakat lainnya.

\section{b) Tugas dan Fungsi}

Setiap karang taruna mempunyai tugas pokok dan fungsi secara bersama-sama dengan pemerintah dan komponen masyarakat lainnya untuk mewujudkan kesejahteraan terutama yang diahadapi oleh generasi milenial dan pengembangan potensi generasi milenial di lingkungannya.

Setiap karang taruna melaksanakan fungsi, yaitu:

a. Penyelenggara usaha kesejahteraan sosial.

b. Penyelenggara pemberdayaan masyarakat terutama generasi milenial di lingkungannya secara komprehensif, terpadu, terarah, serta berkesinambungan.

c. Penyelenggara kegiatan pengembangan jiwa kewirausahaan bagi generasi milenial di lingkungannya.

d. Penanaman pengertian, memupuk, dan meningkatkan kesadaran tanggung jawab sosial generasi milenial.

e. Penumbuhan dan pengembangan semangat kebersamaan, jiwa kekeluargaan, kesetiakawanan, jiwa sosial, memperkuat nilai-nilai kearifan lokal dan Negara Kesatuan Republik Indonesia.

f. Pemupukan kreatifitas generasi milenial untuk dapat mengembangkan tanggung jawab sosail yang bersifat rekreatif, kreatif, edukatif, ekonomis, produktif, dan kegiatan praktis lainnya dengan mendayagunakan segala sumber dan potensi kesejahteraan sosial di lingkungannya secara swadaya.

g. Penguatan sistem jaringan komunikasi, kerjasama, informasi, dan kemitraan dengan berbagai sektor lainnya.

h. Penyelenggara usaha-usaha pencegahan permasalahan sosial yang aktual.

\section{c) Program-Program Karang Taruna Bakti}

1. Bidang Kesekretariatan

2. Bidang Usaha Kesejahteraan Sosial.

3. Bidang Usaha Ekonomi Produktif

4. Bidang Pendidikan dan Latihan

5. Bidang Keagamaan/Kerohanian

6. Bidang Pengabdian Masyarakat.

7. Bidang Olahraga dan Seni. 


\subsection{Hasil dan Pembahasan}

\subsubsection{Proses pemberdayaan}

Keberadaan Karang Taruna sebagai organisasi sosial wadah pengembangan generasi milenial mempunyai posisi yang cukup strategis dan semakin diperlukan dalam menjawab permasalahan sosial, terutama permasalahan yang dihadapi masyarakat yang ada Dusun Munegan Desa Sidoluhur.Generasi milenial menjadi potensi terbesar karena dalam usia demikian penuh dengan jiwa yang dinamis, semangat, kuat fisik dan mental serta berbagai kelebihan lain. Generasai milenial ini menjadi stakeholder pembangunan berkelanjutan dengan memanfaatkan bantaran sungai sebagai lahan produktif. Hal ini dapat menjadi modal dasar kekuatan bagi pendukung keberlangsungan dalam pembangunan dan mengatasi persoalanpersoalan di masyarakat Dusun Munengan, terutama dalam hal pemanfaatan dan pengelolaan bantaran Sungai Bedog menjadi lahan yang produktif. Kemudian dapat memperbaiki dan melindungi dari kerusakan sungai akibat dari sampah dan abrasi yang terjadi di Sungai Bedog Dusun Munengan.

Generasi yang tergabung dalam Komunitas Karang taruna di Dusun Munengan Desa Sidoluhur ini dapat dikatakan sudah menginjak usia dewasa.Maka proses pemberdayaan melalui beberapa tahap, yaitu: pertama, penyadaran yaitu proses menumbuhan kesadaran pada generasi milenial yang menjadi target perubahan. Kedua, refleksi yaitu proses setelah tahap penyadaran berhasil dilakukan maka dilakukan perencanaan perubahan sosial sesuai sasaran. Ketiga, aksi yaitu proses yang dilakukan sebagai bentuk konkret dalam melakukan perubahan sesuai yang direncanakan sebelumnya untuk mencapai tujuan bersama. Proses ini sejalan dengan teori transformatif (Mezirow, 1991). Hal ini bertujuan supaya sasaran/masyarakat memiliki kesadaran dan melakukan aksi perubahan ke arah yang lebih maju. Kemudian proses pembelajaran menggunakan prinsip andragogy (Knowles, 1970) karena sebagian besar anggota dari Komunitas Karang Taruna Bakti sudah di kategori orang dewasa sehingga proses pembelajarannya menggunakan pendekatan pendidikan orang dewasa. Yang mana pendekatan orang dewasa lebih menekankan padapelibatan penuh orang dewasa (sasaran) dalam proses penyelesaian masalah, artinya seorang pengembang sebagai seorang yang membantu dan mengarahkan sasaran untuk berpikir dalam menyelesaikan permasalahan yang dihadapi. Konteks sasaran dalam artikel ini yaitu pemuda Komunitas Karang Taruna Bakti di Dusun Munengan Desa Sidoluhur.

Proses pemberdayaan melalui Komunitas Karang Taruna Bakti ini melalui tiga tahapan, yaitu sebagai berikut.

a) Tahap Penyadaran

Pada tahap ini pengembang melakukan pendekatan kepada pemuda Karang Taruna Bakti Dusun Munengan Desa Sidoluhur melalui kegiatan outbound untuk menciptan suasana yang menyenangkan dan nyaman serta memiliki kedekatan dengan pengembang. Kegiatan outbound ini dilaksanakan di kolam ikan sekitar bantaran Sungai Bedog. Kegiatan outbound yang menyenangkan, nyaman, dan penuh kedekatan bisa menjadi salah satu faktor yang menumbuhkan kesadaran diri pemuda akan pentingnya menjaga dan melestarikan lingkungan (Ritzer \& Goodman, 2008).

Selanjutnya melakukan kegiatan diskusi bersama membangun komunikasi yang baik dan melibatkan partisipasi para pemuda dalam perencanaan membangun desa menuju pembangunan berkelanjutan (sustainable development goals). Tilaar, (2009) mengungkapkan partisipasi adalah sebagai wujud dari keinginan untuk mengembangkan demokrasi melalui proses desentralisasi dimana perlunya perencanaan dari bawah (bottom-up)dengan mengikutsertakan sasaran/masyarakat dalam proses perencanaan dan pembangunan masyarakatnya. Sehingga dengan pelibatansasaran/masyarakat akan muncul rasa memiliki pada dirinya.Tujuannya kegiatan ini menumbuhkan kesadaran supaya timbul keinginan dari para pemuda Karang Taruna Bakti Dusun Munengan Desa Sidoluhur untuk aktif berpartisipasi dalam rangka pembangunan desa salah satunya melalui penataan bantaran Sungai Bedog di Dusun Munengan Desa Sidoluhur. 
Pada intinya tahap penyadaran ini menekankan bahwa pentingnya bagi sasaran/masyarakat memiliki kesadaran untuk berpartisipasi mulai dari proses identifikasi permasalahan, perencanaan kegiatan, pelaksanaan kegiatan, danmengevaluasi kegiatan pengelolaan lahan bantaran Sungai Bedog di Dusun Munengan Desa Sidoluhur. Program kegiatan yang dijalankan ialah sebagai upaya melestarikan lingkungan yang berkelanjutan. Ife (2014) menyatakan dalam bukunya "Community Development"bahwa penting mempertimbangkan perspektif ekologi, perspektif keadilan sosial, dan HAM (Hak Asasi Manusia), kemudian perspektif ekologi dan keadilan sosial menjadi visi dalam pengembangan masyarakat, menciptakan perubahan dari bawah atau button-up, dan melibatkan partisipasi masyarakat dalam proses pemberdayaan masyarakat. Berdasarkan pendapat tersebut, tentunya semakin meyakinkan bahwa proses pemberdayaan di masyarakat harus ada pelibatan kepada masyarakat, partisipasi masyarakat (Pemuda Karang Taruna Bakti) dalam proses perencanaan, pelaksanaan, dan evaluasi kegiatan pengelolaan bantaran Sungai Bedog di Dusun Munengan sangat menentukan tingkat keberhasilan pemberdayaan masyarakat dan pembangunan berkelanjutan.

b) Tahap Refleksi

Pada tahap ini pengembang memberikan stimulan atau rangsangan kepada para pemuda Karang Taruna Bakti untuk merenungkan kembali akan pentingnya menjaga lingkungan terutama dalam hal ini ialah menjaga lingkungan bantaran sungai. Pengembang dan pemuda Karang Taruna Bakti melakukan workshop dan kegiatan nonton bersama. Film yang ditampilkan ialah yang berkaitan dengan sebab akibat dari bantaran sungai yang tidak terjaga, dan manfaat penataan bantaran sungai yang telah tertata dan terlindungi kelestarian lingkungan. Hal ini bertujuan menjalankan komunikasi kelompok sebagai interaksi tatap muka yang bertujuan membentuk konsep diri yang baru, yakni konsep diri ke arah yang lebih baik.

Burgoon dalam Wonodiharjo (2014) menyatakan bahwa komunikasi kelompok sebagai interaksi tatap muka dari tiga atau lebih individu guna memperoleh maksud dan tujuan yang dikehendaki seperti berbagi informasi, pemeliharaan diri atau pemecahan masalah sehingga semua anggota dapat menumbuhkan karakteristik pribadi anggota lainnya dengan akurat. Karakteristik ini kemudian dapat dijadikan sebagai bagian dari refleksi diri dan pembentukan konsep diri seseorang untuk komitmen berubah menjadi lebih baik. Konsep diri di sini adalah gambaran atau pandangan secara menyeluruh mengenai diri oleh individu yang bersangkutan, dari konsep diri ini akan menentukan bagaimana individu tersebut berperilaku, merasakan, dan merespon lingkungannya. Individu yang memilki konsep diri yang positif menghasilkan bentuk prilaku yang mandiri, menghargai diri sendiri dan orang lain serta percaya diri yang tinggi, dalam artian konsep diri yang positif mempengaruhi perilaku yang konstruktif (Situmorang, 2009).

Output dari tahap refleksi ini ialah menghasilkan perencanaan dalam penataan bantaran Sungai Bedog. Pertama, perencanaan melakukan aksi gotong royong membersihkan bantaran Sungai Bedog. Kedua, perencanaan menanam pohon di sekitar bantaran Sungai Bedog tanaman yang di pilih ialah tanaman jambu air dan markisa. Tanaman jambu air dipilih karena cocok dengan struktur tanah di sekitar bantaran sungai dan lokasi tanah berada pada ketinggian \pm 1.000 mdpl. Tanaman jambu air dan markisa tumbuh optimal pada daerah bercurah hujan rendah dengan musim hujan tidak lebih dari 8 bulan serta memiliki akar tunggang dan dalam sehingga dapat menjaga struktur tanah (Yuliantoro, 2016).

\section{c) Tahap Aksi}

Pada tahap ini pengembang dan pemuda Karang Taruna Bakti melakukan kegatan aksi menata bantaran Sungai Bedog dan melakukan gotong-royong membersihkan lingkungan sekitar bantara Sungai Bedog. Aksi itu sendiri ialah individu atau kelompok melakukan suatu tindakan berdasarkan atas pengalaman, persepsi, pemahaman, dan penafsirannya atas suatu objek stimulus atau situasi tertentu serta untuk mencapai tujuan 
tertentu (Ritzer, 1985).Kegiatan ini tentunya merupakan tindakan yang dilakukan setelah melewati tahap penyadaran dan refleksi sehingga pemuda Karang Taruna Bakti tumbuh kesadaran dan mulai melakukan perubahan terutama untuk menata bantaran Sungai Bedog menjadi lebih baik dan terlindungi ekosistemnya dari permasalahan sampah.

Aksi pemuda Karang Taruna Bakti selanjutnya ialah dalam rangka pemanfaatan bantaran Sungai Bedog ialah program penanaman pohon jambu air dan pohon markisa di sekitar bantaran Sungai Bedog. Manfaat yang bisa diperoleh dari aksi program penanaman pohon ini ialah selain dapat menahan tanah dari abrasi air sungai dan juga bisa memanfaatkan lahan bantaran sungai dengan tanaman yang menghasilkan yaitu buah jambu air dan buah markisa. Berdasarkan hasil penelitian Sittadewi (2008) menunjukan bahwa tanaman pepohonan yang terdapat di bantaran sungai berfungsi untuk menjaga stabilitas tebing sungai dari gempuran arus air, dari energi mekanik hujan, dan dari peresapan air ke pori-pori rekahan tebing sungai. Ranting, cabang dan daun tanaman yang tumbuh di pinggir sungai berperan sebagai komponen pemecah energi mekanik arus air maupun air hujan, juga berfungsi sebagai pengarah arus dan pengarah aliran sekunder memanjang sungai. Akarpohon tanaman berfungsi sebagai komponen stabilitas tebing sungai dan sebagai barrier (penangkal) untuk mengurangi erosi akibat gerusan tebing maupun erosi dari aliran permukaan.

Adanya penataan bantaran Sungai Bedog dan dikelola dengan baik tentunya program ini akan bermanfaat ganda, yaitu terjaga kelestarian ekologi lingkungan bantaran sungai dan buah yang dihasilkan dari pohon jambu air dan pohon markisa. Selain itu, guna mengoptimalkan lahan bantaran Sungai Bedog yang selama ini belum dimanfaatkan secara maksimal.

\subsubsection{Pelaksanaan tata kelola dan manfaat tata kelola bantaran sungai}

Menata bantaran sungai dengan melakukan gotong royong kebersihan bersama Karang Taruna Bakti. Kemudian menanam pohon jambu air dan pohon markisa sebagai aksi dari program tata kelola bantaran sungai ini. Pelaksanaan aksi gotong-royong membersikan bantaran Sungi Bedog ini pada hari Sabtu, 17 November 2018 yang di inisiasi oleh pengembang dan Karang Taruna Bakti Dusun Munengan Desa Sidoluhur.

Proses tata kelola bantaran sungai akan lebih efektif jika didorong oleh faktor dari dalam yang sering disebut sebagai immanent change, di mana perubahan ditemukannya berbagai inovasi baru dalam masyarakat itu sendiri. Perubahan semacam ini tidak membutuhkan berbagai macam penyesuaian sosial masyarakat karena berasal dari masyarakat itu sendiri. Dalam konteks tata kelola bantaran Sungai Bedog ini merupakan gerakan yang dilakukan secara bersama-sama dari pengembang dan Komunitas Karang Taruna Bakti Dusun Munengan Desa Sidoluhur.

Pengelolaan bantaran sungai sebagai bagian pengelolaan lingkungan memiliki tantangan yang sangat mendasar yaitu bagaimana mengelola sumber daya sungai dan daya dukung lingkungan bagi manfaat manusia secara optimal dan berkelanjutan. Sumber daya alam dan daya dukung lingkungan dari kawasan sungai harus dikembangkan sedemikian sehingga menguntungkan secara sosial-ekonomi dan ramah lingkungan. Pelaksanaan program menanam pohon jambu air dan pohon markisa di sekitar bantaran Sungai Bedog dilaksanakan oleh pengembang dengan pemuda Karang Taruna Bakti pada hari Sabtu, 1 Desember 2018.

Berdasarkan hasil pelaksanaan pemanfaatan bantaran sungai memberikan manfaat bagi lingkungan terutama menjaga kelestarian ekologi bantaran sungai, selain itu juga membuat lingkungan bantaran sungai menjadi lebih tertata dan enak dipandang yang menambah nilai estetika. Manfaat lain dari penanaman pohon jambu air dan markisa ini ialah menahan struktur tanah dari abrasi. Penanaman pohon yang sesuai di sekitar sungai atau mata air berperan dalam menjaga kelestarian mata air, menahan struktur tanah dari abrasi dan ketersediaan air di kawasan tersebut (Trimanto, 2013). Buah dari jambu air dan markisa bisa di manfaatkan atau dijual 
sebagai upaya peningkatan perekonomian masyarakat terutama di Dusun Munengan Desa Sidoluhur, Kecamatan Godean, Sleman, Yogyakarta.

\section{SIMPULAN DAN SARAN}

\subsection{Simpulan}

Berdasarkan uraian dari hasil penelitian dan pembahasan yang telah dilakukan, maka peneliti dapat menarik kesimpulan yaitu:

Pertama, pemberdayaan masyarakat melalui Komunitas Karang Taruna Bakti sebagai upaya pengelolaan bantaran sungai Bedog dimulai dari proses penyadaran, pada tahap ini pengembang melakukan pendekatan kepada pemuda karang taruna Bakti serta melalui kegiatan outbound untuk menciptan suasana yang menyenangkan, nyaman, dan penuh kedekatan bisa menjadi salah satu faktor yang menumbuhkan kesadaran diri pemuda akan pentingnya menjaga dan melestarikan lingkungan. Proses refleksi, yaitu pengembang dan pemuda Karang Taruna Bakti melakukan workshop dan nonton bareng. Tahap ini menjalankan komunikasi kelompok sebagai interaksi tatap muka yang bertujuan membentuk konsep diri yang baru, yakni konsep diri ke arah yang lebih baik. Tahap aksi yaitu melakukan gotong-royong membersihkan lingkungan sekitar bantaran sungai kemudian menanam pohon jambu air dan pohon markisa di sekitar bantaran sungai guna mengoptimalkan lahan bantaran Sungai Bedog yang selama ini belum dimanfaatkan secara maksimal.

Kedua, upaya pengelolaan bantaran Sungai Bedog menjadi bermanfaat bagi lingkungan dan masyarakat Dusun Munengan Desa Sidoluhur, tanaman jambu air dan markisa akan menghasilkan buah dan pohonnya dapat memelihara ekologi lingkungan bantaran sungai. Selain itu, manfaatnya yaitu menahan struktur tanah dari abrasi dan mendukung pilar pembangunan berkelanjutan.

\subsection{Saran}

Upaya pemberdayaan masyarakat melalui Komunitas Karang Taruna Bakti sebaiknya lebih berkoordinasi dengan masyarakat agar kegiatan yang dilakukan dapat efisien dan tepat sasaran. Sehingga tujuan yang diinginkan bersama dapat tercapai. Untuk mengatasi permasalahan yang dihadapi oleh Karang Taruna Bakti dalam hal meningkatkan kesadaran masyarakat dapat dilakukan dengan pendekatan oleh pengurus dan anggota masyarakat dengan cara berdiskusi dan membentuk kelompok sadar lingkungan. Diharapkan adanya pendampingan yang berkelanjutan oleh dinas terkait untuk senantiasa meningkatkan kualitas pengelolaan bantaran sungai terutama di Sungai Bedog.

\section{DAFTAR PUSTAKA}

Abdoellah, O.S. 2016. Pembangunan Berkelanjutan Di Indonesia. Jakarta: Gramedia Pustaka Utama. 35 pp.

Follet , M.P. 1997. Manajemen Dalam Organisasi. Jakarta: Kencana. 12 pp.

Ife, J.\& Tesoriero F. 2014. Community Development Alternatif Pengembangan Masyarakat di Era Globalisasi. Yogyakarta: Pustaka Pelajar.

Knowles, M. S. 1970. The modern practiesof adult aduce education, andragogy versus pedagogi. New York: Association Press. 78 pp.

Mawardi, I. 2010. "Kerusakan Daerah Aliran Sungai dan Penurunan Daya Dukung Sumberdaya Air di Pulau Jawa serta Upaya Penanganannya". Jakarta: Jurnal Hidrosfir, 5(2): 111.

Mezirow, J. 1991. Transformative dimensions of adult learning. San Francisco, CA: Jossey-Bass. 158 pp.

Peraturan Pemerintah No. 38 Tahun 2011. Tentang Sungai.

Ritzer, G. \& Goodman, D.J. 2008. Teori Soisologi Modern. Jakarta: Prenada Media. 178 pp.

Ritzer, G. 2018. Sosiologi Ilmu Pengetahuan Berparadigma Ganda. Edisi 13. Jakarta: Rajawali Pers. 45 pp. 
Sittadewi, E. H. 2008. Identifikasi Vegetasi Di Koridor Sungai Siak dan Peranannya dalam Penerapan Metode Bioengineering. Jurnal Sains dan Teknologi Indonesia, 10 (2): 122-118.

Situmorang, L.B 2009. "Konsep Diri Pada Mahasiswa Mapasadha (Mahasiswa Pencinta Alam Sanata Dharma)". (skripsi). Yogyakarta: Sanata Dharma University.

Sujarto, D. .1993.“Kinerja dan Dampak Tata Ruang dalam Pembangunan Kota Baru. Studi Kasus Kota terpadu Bumi Bekasi Baru". (disertasi). Bandung: Teknologi Bogor Institude.
Tillar, H.A.R. 2009. Kekuasaan dan Pendidikan: Kajian Menejemen Pendidikan Nasional dalam Pusaran Kekuasaan. Jakarta: Rinika Cipta.

Trimanto. 2013. Diversitas Pohon Sekitar Aliran Mata Air Di Kawasan Pulau Moyo Nusa Tenggara Barat. Conference Paper, Surakarta: Surakarta State Univercity.

Wonodihadrjo, F. 2014. Komunikasi Kelompok Yang Mempengaruhi Konsep Diri Dalam Komunitas Cosplay "COSURA". Surabaya:Jurnal E- - Komunikasi, 2 (3): 1-10.

Yuliantoro, D. 2016. Pohon Sahabat Air. Surakata: Balai Penelitian dan Pengembangan Teknologi Pengelolaan Daerah Aliran Sungai. 25 pp. 